\section{International Journal of Karamanoglu Mehmetbey Educational Research}

ULUSLARARASI

KARAMANOĞLU MEHMETBEY EĞ

Cilt 3 -Özel Sayı 1 Eylül 2021

\title{
Türkçenin Yabancı Dil Olarak Öğretimi Programının 21. Yüzyıl Becerileri Kapsamında İncelenmesi
}

\section{Examining the Curriculum of Teaching Turkish as a Foreign Language in the Scope of 21st Century Skills}

\section{*1 Semih Alper Dündar $\quad{ }^{2}$ Alp Polat}

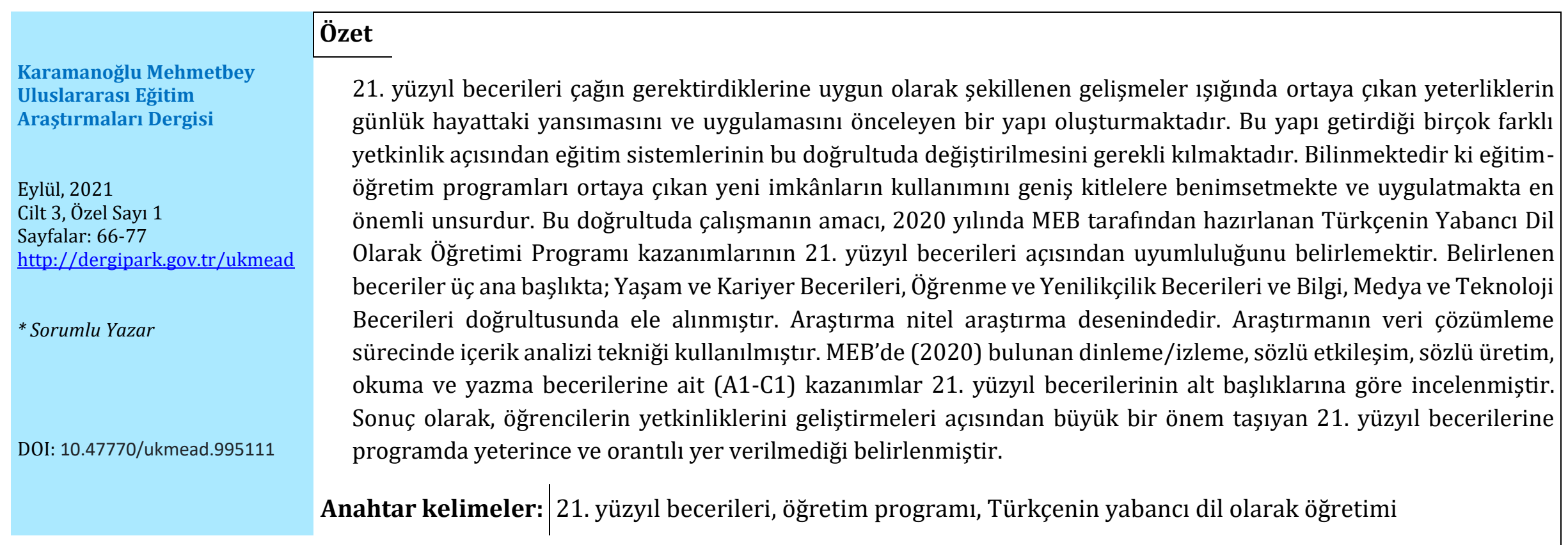

\section{Abstract}

21st-century skills constitute a structure that prioritizes the reflection and application of competencies in daily life in the light of developments shaped in accordance with the requirements of the age. It is known that education and training programs are the most important elements in making the use of new opportunities adopted by large masses and making them enforced. In this direction, the study aims to determine the compatibility of the achievements of the Curriculum for Teaching Turkish as a Foreign Language, prepared by the Ministry of National Education in 2020, in terms of 21st-century skills. The determined skills are under three main headings; Life and Career Skills, Learning and Innovation Skills, and Information, Media, and Technology Skills. The research is in the qualitative research design. Content analysis technique was used in the data analysis process of the research. As a result, it has been determined that 21st-century skills, which are of great importance for students to develop their competencies, are not adequately and proportionally included in the program.

International Journal of Karamanoğlu Mehmetbey Educational Research

September, 2021 Volume 3, Special Issue 1 Pages: 66-77 http://dergipark.gov.tr/ukmead

* Corresponding author DOI: $10.47770 /$ ukmead.995111

\footnotetext{
${ }^{1}$ Dr. Öğr. Gör.; Ankara Yıldırm Beyazıt Üniversitesi, DILLMER, sadundar@,ybu.edu.tr

$2 \ddot{O g r}$. Gör.; Hatay Mustafa Kemal Üniversitesi, TÖMER, alp.polat@,mk.u.edu.tr
} 


\section{GíRiş}

Okuryazar olmak, okuma ve yazmayı işlevsel kullanmak ya da aritmetik bilgisine sahip olmak 20. yüzyılda başarılı olabilmek için yeterli görülen beceriler arasındaydı. Bunun yanında, günümüz dünyasında başarılı olabilmek, öğrencilerin 21. yüzyılın getirdiği yeniliklere koşut; işbirlikli çalışma, eleştirel düşünme, iletişim teknolojilerine hâkimiyet, esneklik ve uyum yeteneği, girişimcilik vb. bir dizi beceriye sahip olmayı gerektiren ve daha donanımlı bireylerin yetişmesini şart koşan bir yapıyı ortaya koymaktadır.

21. yüzyıl becerileri, bilgiyi kazanma ve yeni durumlara aktarılabilme veya uygulayabilme becerileri olarak düşünülebilir. Pellegrino ve Hilton'a (2012) göre bilginin aktarılması olarak bahsedilen unsur hem bir alana ait içerik bilgisi hem de sorunların ortadan kaldırılması adına bilginin ne zaman, nerede ve ne şekilde kullanılabileceğine dair işlemsel bilgiyi de içermektedir. Burada bahsi geçen işlemsel bilgi "beceriler" olarak tanılanmaktadır (Pellegrino ve Hilton, 2012, s. 23). Mevcut çağın bağlamı ile ilişkili olarak şekillenen bu beceriler bilginin daha etkili kullanımını ve geniş pencereden ele alınmasını sağlamaktadır.

21. yüzyılın gerektirdiği koşullar bilinmesine rağmen olanakların ve yönelimlerin çok hızlı bir değişkenlik içinde olması, söz konusu becerilere ait sınırların belirlenmesini zorlaștırmaktadır. Bunun bir göstergesi, konu üzerine fikir ortaya koyan kaynakların bu beceriler hakkında getirdikleri farklı tanımlamalardır. Bu kaynakların ortaya koyduğu resme göre açık ve uzlaşımsal bir tanım ortaya çıkmamakla birlikte; 21. yüzyıl becerileri, günlük ve profesyonel hayatta başarıya ulaşmak için gereken bilgi, beceri ve uzmanlığın harmanlanmış hâlini ifade eder (Ledward ve Hirata, 2011 akt. Gelmez, Burakgazi vd., 2019). Silva'ya (2009, s. 22) göre; teknoloji okuryazarlığı, uygulamalı beceriler, kişilerarası beceriler, dijital medya okuryazarlığı gibi geniş bir yelpazeyi içine almaktadır.

21. yüzyıl becerileri, genel bir bakış açısı içinde değerlendirildiğinde ise birçok kişi, kurum ve kuruluş tarafından ortaya konmaya çalışılmıştır. Bazı kaynaklar bu becerilerle ilgili olarak; "derin öğrenme becerileri (deep learning skills)", "gerekli beceriler (necessary skills)", "hayatta kalma becerileri (survival skills)", "istihdam edilebilirlik becerileri (employability skills)", "temel yeterlikler (key competences)" gibi farklı özellikleri yansıtan isimler vermişlerdir (European Parliament and the Council, 2006). Beceriler hakkında ortaya koyulan sınırlandırmalar birbiri ile paralel olmanın yanında çok farklı özelliklerin bileşkesini ifade etmektedir.

21. yüzyıl becerilerinin hangileri olduğu, uygulama şekilleri, nasıl sınıflandırıldığı, nasıl kazandırılacağı ve değerlendirme ölçütlerinin ne olacağı konusunda birçok çalışma yayımlanmıștır. Bu çalışmalar içerisinde küresel anlamda önem kazanan sekiz kurumun dünyadaki eğitim kurumlarının işleyişine yön veren değerlendirmeleri önem kazanmaktadır. Bu kurumların listesini şu şekilde sıralamak mümkündür:

1. 21. Yüzyıl Becerileri İçin Ortaklık - P21

2. Küresel Eğitim için Asya Toplum Merkezi -ASIA Society

3. Dünya Bankası

4. Avrupa Birliği-AB

5. Birleşmiş Milletler Eğitim, Bilim ve Kültür Örgütü -UNESCO

6. Dünya Ekonomik Forumu- WEF

7. Ekonomik İşbirliği ve Kalkınma Örgütü-OECD

8. Eğitimde Teknoloji için Uluslararası Toplum - ISTE

(Yeniay Üsküplü, 2019, s. 68)

Yukarıda belirtilen kurumlara ek olarak 21. yüzyıl becerileri hakkında alanyazında birçok çerçeve ortaya koyulmuştur. Bu çerçeveler çağın gerektirdiklerinin hangi beceriler olduğunu farklı bakış açıları ile ele almıştır: 
Tablo 1.

Farklı Kurumlar Tarafindan Belirlenen 21. Yüzyıl Becerileri

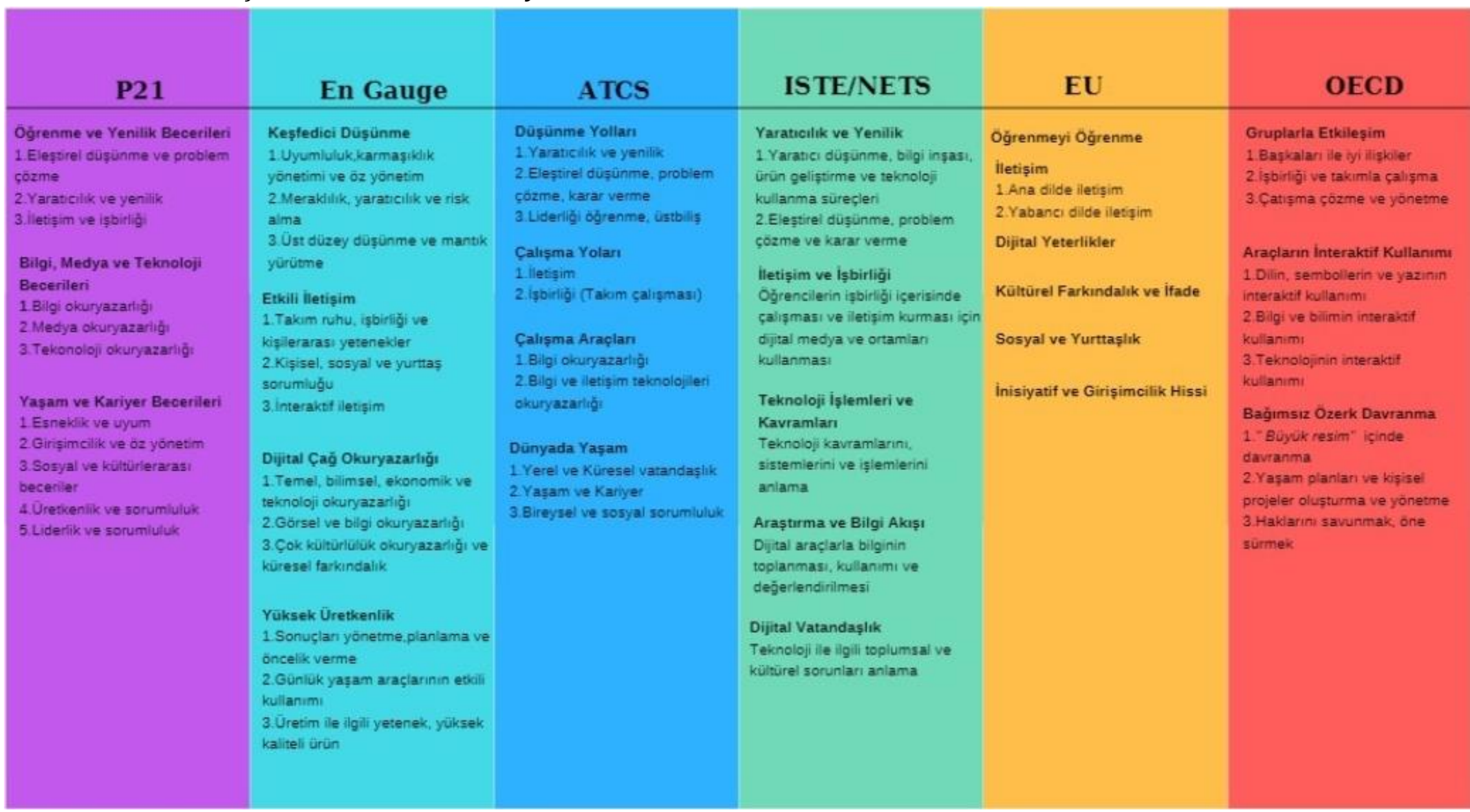

Kotluk, N. ve Kocakaya, S. (2015)'ten uyarlanmıştır. (Benek, 2019, s. 65)

Farklı yaklaşımlar doğrultusunda ortaya koyulan 21. yüzyıl beceri çerçeveleri incelendiğinde işbirlikli çalışma, medya okuryazarlığı ve dijital okuryazarlık, bireysel ve sosyal sorumluluk, girişimcilik ve çözüm odaklı olma, iletişim yeterlikleri, yaratıcılık gibi başlıkların genel olarak büyük bir öneme sahip olduğu sonucuna varılabilir. Bunun yanında çok kültürlülüğe saygı, kültürlerarası uyum, teknoloji okuryazarlığı ile ana ve yabancı dil yeterlikleri ön plana çıkan diğer beceriler olarak karşımıza çıkmaktadır. Burada sayılan becerilerin üst düzey düşünmeye yönlendiren ve sosyal ilişkileri geliştiren yapısı, gelecek kuşaklar için son derece önemli zeminler oluşturmaktadır.

Yukarıda alt başlıkları ile birlikte bahsedilen çerçeveler arasında Partnership for 21st Century Skills'in (P21) belirlemiş olduğu çerçeve, alanyazında daha fazla ön plana çıkmış ve kabul görmüştür.

Çağın gerektirdiği beceriler eğitim yolu ile edinileceği için eğitim programları kilit bir rol üstlenmektedir. Çünkü bu yeterlikler; yalnız bilgiye sahip olmayı değil aynı zamanda bilgiye nasıl ulaşılması gerektiğini ve onu etkili kullanmayı amaç edinmektedir. Bu bakımdan 21. yüzyıl becerileri işbirliğine, yaratıcılığa, yansıtıcı düşünmeye, biliş ve bilişüstü yaklaşımlara, problem çözmeye öncelik tanır. Teknolojik yeterliklere sahip olabilme ve okuryazarlıklar (bilgi, medya, dijital çağ) önemlidir. Böylece geleceğin model davranışları ortaya çıkarılabilecek ve etkililik sağlanabilecektir.

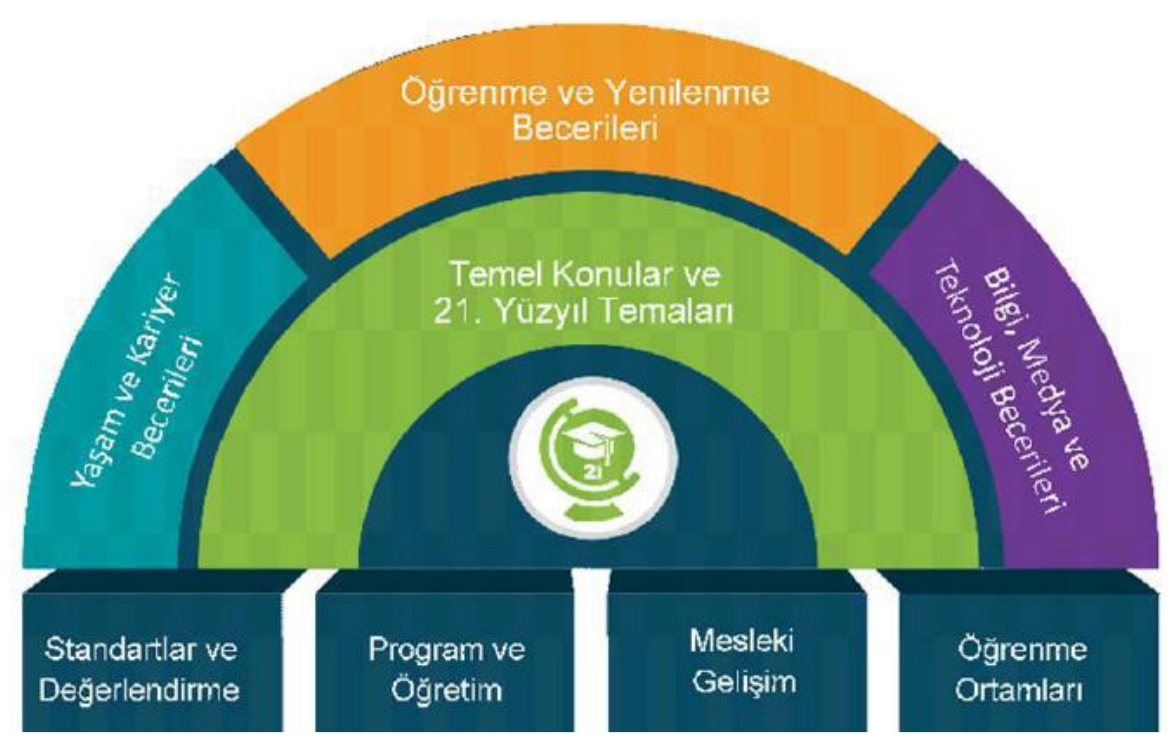

Şekil 1. P21 21. Yüzyıl Becerileri Çerçevesi (Battelle for Kids, 2019)

Şekil 1'de 21. yüzyılın gerekliliklerine uygun olduğu düşünülen alanlar ortaya konmuştur. P21-21. Yüzyıl Öğrenme Çerçevesine göre bireylerin sahip olması gereken yeterlilikler ise şu şekilde ifade edilmiştir: 
1. Yaşam ve kariyer becerileri, esneklik, uyum sağlayabilirlik, girişkenlik, kendini yönetme, sosyal ve kültürlerarası beceriler, üretkenlik, sorumluluk ve liderlik.

2. Bilgi, medya ve teknoloji becerileri; bilgi okuryazarlığı, medya okuryazarlığı ve teknoloji okuryazarlığıdır.

3. Ögrenme ve yenilikçilik becerileri; yaratıcılık, yenilik, eleştirel düşünme, problem çözme, iletişim ve iş birliğidir (P21, 2003, s.11).

P21'e göre ortaya koyulan 21. yüzyıl beceri çerçevesi üç ana başlık altında toplanmıștır. Bireylerin bilginin sadece sahibi olmasının yanı sıra onu hayatta nasıl uygun şekilde ve etkili kullanması gerektiğini ortaya koyan, iletişimsel hedeflere ve üst düzey düşünmeye yönelik olarak hazırlanan P21'in alt başlıkları şekil 2'de gösterilmiştir:

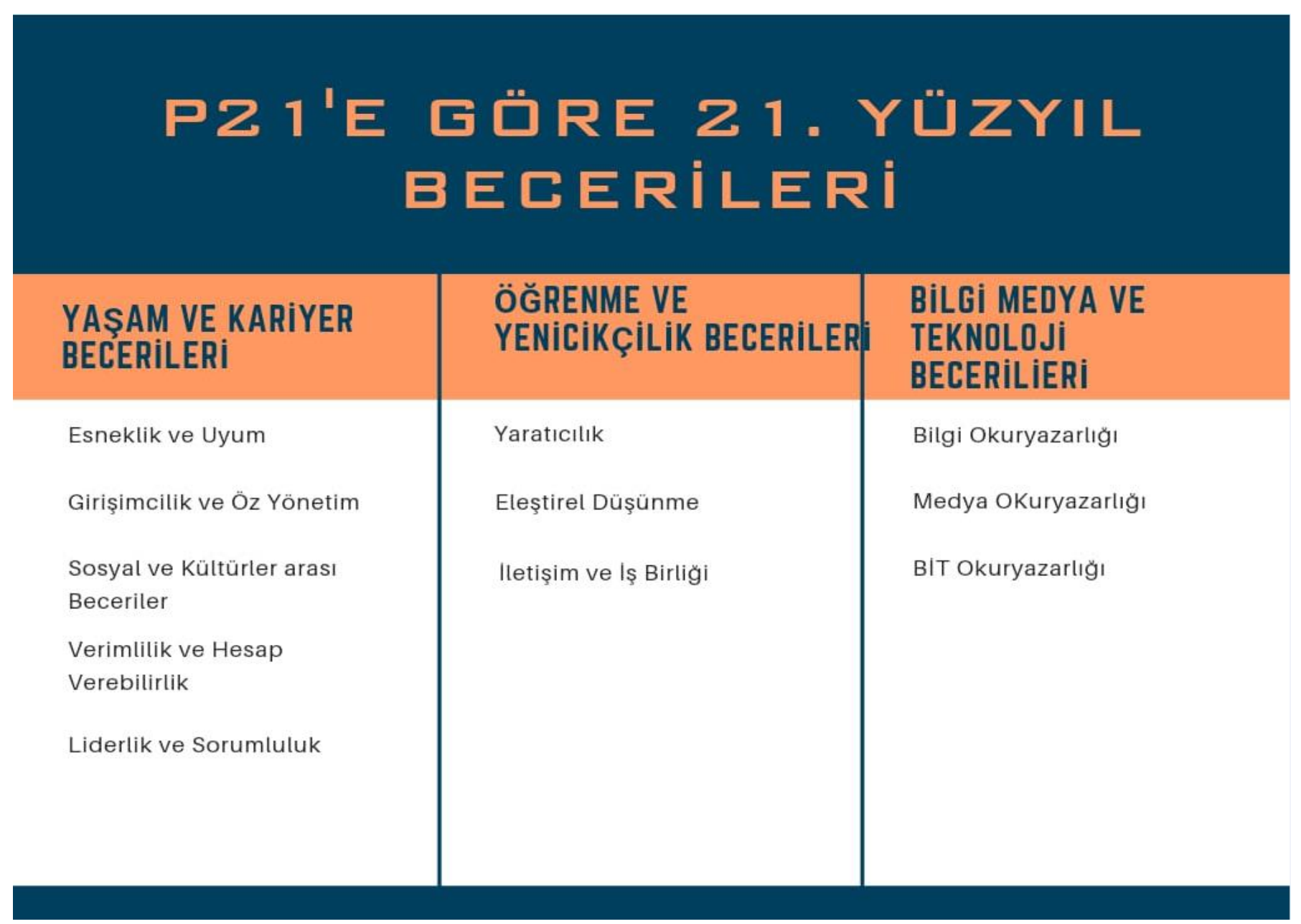

Şekil 2. P21'e Göre 21. Yüzyıl Becerileri

21. yüzyıl becerileri çerçevesi içerisinde yer alan yukarıdaki ana başlıklar öğrencilerin zihinsel, sosyal, iletişimsel yeterliklerini üst seviyeye çıkarmaya ve gelişimlerini ileri taşımaya yönelik hedefleri içinde barındırmaktadır. Burada önemli husus, bu hedeflerin öğrencilerin eğitim-öğretim süreçlerine ne şekilde dâhil edileceğidir. Bu amaca ulaşmanın ilk aşaması, öğretim programlarının ve buna bağlı şekillenen kazanımların 21. yüzyıl becerileri ile bütünleşik bir anlayış içerisinde oluşturulmasıdır. Așamalı olarak bu süreç; ders kitaplarının, oluşturulacak metinlerin ve etkinliklerin de aynı yaklaşım ile şekillendirilmesini zorunlu kılmaktadır.

Öğretim programlarının 21. yüzyıl becerileri doğrultusunda bir görünüm kazanması ana dili ve yabancı dil öğretimi açısından son derece önemlidir. Çeşitli kurum ve kuruluşlar tarafından belirlenmeye çalışılan 21. yüzyıl beceri çerçeveleri içerisinde çokça bahsedilen "küresel vatandaşlık, çok kültürlülük okuryazarlığı, ana ve yabancı dilde iletişim" gibi kavramlar ana dilinin yanı sıra yabancı dil öğretiminin içinde bulunduğumuz çağ için ne denli gerekli olduğuna vurgu yapmaktadır. Aynı yaklaşım MEB tarafından da ortaya koyulmuş ve 2018 Türkçe Dersi Öğretim Programı'nda (İlkokul ve Ortaokul 1, 2, 3, 4, 5, 6, 7 ve 8. Sınıflar) Türkiye Yeterlilik Çerçevesi (TYÇ) kapsamında "Yabancı Dillerde İletişim" başlı̆̆ ile yer almıştır (MEB, 2018, s. 4-5). Türkçenin yabancı dil olarak öğretimi noktasında çağın gerektirdiği yeterlikler ile bütünleşik bir öğretim programına sahip olmak kültürel etkileşimin hızla geliştiği dünyada artı bir özellik olarak karşımıza çıkacaktır.

Öğretim programlarının eğitimde gerçekleştirilmek istenen atılımların ve ortaya koyulan yeniliklerin takibinde başat rolü dikkate alındığında bu çalışmanın amacı; 2020 yılında Millî Eğitim Bakanlığı adına PIKTES (Suriyeli Çocukların Türk Eğitim Sistemine Entegrasyonunun Desteklenmesi Projesi) ve Türkiye Maarif Vakfı'nın iş birliğiyle yürütülen çalışmalara farklı üniversitelerden pek çok uzman ve akademisyenin katılımıyla oluşturulan Türkçenin Yabancı Dil Olarak Öğretimi Programı'na ait kazanımların P21 becerileri çerçevesine uygunluğunu incelemektir. Çalışma ile 21. yüzyıl beceri çerçevesinin programdaki karşılığının ne seviyede olduğu ortaya koyulacaktır. Büyük bir emeğin karşılığı olan ve Türkçenin yurt içi ve yurt dışında yabancı dil olarak öğretimine yönelik artan ihtiyaç nedeniyle hazırlanan bu program ile Türkçe öğrenmek isteyen öğrencilerin bu yüzyılın gerekliliklerini yerine getirmeleri yolunda önemli bir adım atılmış olacaktır. 
Kısaca, 21. yüzyıl becerileri yeterlik alanları öğrencilerin iletişimsel becerilerini geliștirme, iş birliği içinde çalışma, kültürlerarasılık bilincine sahip olma, girişimcilik ve liderlik rollerini etkin kullanma, dijital okuryazarlık gibi pek çok alanda gelişmişlik seviyelerini yükseltmeyi amaçlayan önemli yaklaşımları içinde barındırmaktadır. Alanda gerçekleştirilen çalışmalarda 21. yüzyıl becerileri, birçok farklı dersin (Fen Bilgisi, Sosyal Bilgiler, Türkçe, Matematik, Biyoloji, Beden Eğitimi, Grafik Tasarım, Okul Öncesi) öğretim programlarındaki işlevselliği, öğretmenlerin ve öğrencilerin 21. yüzyll becerilerine uyumu, eğitim kurumlarının mevzu bahis konuda yeterlikleri, teknoloji kullanımının ve eğitim felsefesinin çağın gerektirdikleri arasındaki ilişki açısında farklı boyutlarda ele alınmaktadır (Atik ve Yetkiner, 2021; Aydemir, Karalı ve Coşanay, 2020; Bozkurt, 2021; Çevik ve Demirtaș, 2021; Demir ve Özyurt, 2021; Devrani, 2021; Engin ve Korucuk, 2021; Erdamar ve Barası, 2021; Gürültü, Aslan ve Alcı, 2020; Işıkgöz, 2021; Kalemkuş, 2021 Kurudayıŏlu ve Soysal, 2019; Özmutlu ve Özmutlu, 2021; Selçuk, 2020; Tuğluk ve Özkan, 2019; Uçak ve Erdem, 2020; Yeni, 2020). Fakat Türkçenin yabancı dil olarak öğretimi programının 21. yüzyıl becerileri çerçevesinde değerlendirildiği bir çalışma bulunmamaktadır. Bu doğrultuda çalışmamızda, MEB tarafından hazırlanan Türkçenin Yabancı Dil Olarak Öğretimi Programı'na ait kazanımlar 21. yüzyıl gereklilikleri açısından ele alınarak incelenmiştir.

\section{Araştırmanın amacı}

Bu çalışmada MEB'de (2020) yer alan dil becerilerine ilişkin kazanımların 21. yüzyıl becerilerine göre incelenmesi amaçlanmıştır. Bu kapsamda çalışmanın alt amaçları şunlardır:

1. Türkçenin yabancı dil olarak öğretimi programında (A1-C1) yaşam ve kariyer becerilerine ilişkin kazanımların tespit edilmesi.

2. Türkçenin yabancı dil olarak öğretimi programında (A1-C1) öğrenme ve yenilikçilik becerilerine ilişkin kazanımların belirlenmesi.

3. Türkçenin yabancı dil olarak öğretimi programında (A1-C1) bilgi, medya ve teknoloji becerilerine ilişkin kazanımların tespit edilmesi.

\section{YÖNTEM}

Türkçenin yabancı dil olarak öğretimi programındaki kazanımların 21. yüzyıl becerileri tarafından incelenmesi amaçlanan bu araştırma nitel araştırma desenindedir. Araştırmanın veri çözümleme sürecinde de içerik analizi tekniği kullanılmıştır. Bu kapsamda MEB'de (2020) yer alan dinleme/izleme, sözlü etkileşim, sözlü üretim, okuma ve yazma becerilerine ait (A1-A2-B1B2-C1) kazanımlar 21. yüzyıl becerilerinin alt başlıklarına göre araştırmacılar tarafından ayrı ayrı analiz edilmiştir. Araştırmacılar arasındaki görüş birliğinin doğrulanmasında ise Miles ve Huberman'ın (1994) formülünden yararlanılmıştır. Bu formül aracıllğıyla yapılan hesaplama sonucunda araştırmacılar arasındaki görüş birliği \%90,5 olarak tespit edilmiştir. Görüş ayrılığl ortaya çıkan \%9,5'luk oranı için araştırmacılar arasında yeniden bir değerlendirme yapılmıștır. Bu değerlendirme sonucunda kalan bölüm üzerinde görüş birliğine varılarak analizlerin son şekli oluşturulmuştur.

\section{BULGULAR}

MEB'de (2020) yer alan A1-C1 düzeylerindeki dil becerilerine ilişkin kazanımlar bu araştırmanın verilerini oluşturmaktadır. Türkçenin yabancı dil olarak öğretimi programında dil becerileri A1 düzeyinde 215, A2 düzeyinde 296, B1 düzeyinde 299, B2 düzeyinde 266 ve C1 düzeyinde 239 kazanımla temsil edilmektedir. Öğretim programındaki A1-C1 düzeylerindeki dinleme/izleme, sözlü etkileşim, sözlü üretim, okuma ve yazma becerilerine ilişkin kazanımlar çalışmanın 21. yüzyıl becerilerini yoklamayla ilgili verilerini oluşturmaktadır. Araștırmada ayrıca incelenen kazanımlarla ilgili örnekler de sunulmuştur.

Çalışmada birinci alt problemi kapsamında Türkçenin yabancı dil olarak öğretimi programı 21. yüzyıl yaşam ve kariyer becerileri açısından incelenmiştir. Bu kapsamda A1-C1 düzeylerindeki kazanımlar esneklik ve uyum, girişimcilik ve özyönetim, sosyal ve kültürlerarası beceriler, verimlilik ve hesap verebilirlik, liderlik ve sorumluluk alt başlıkları altında ele alınmıştır. Kazanımlar analiz edilirken esneklik ve uyum becerileri "yeni öğrenme ortamlarına açık olma ve değişikliklere uyum sağlama", girişimcilik ve özyönetim becerileri "öz düzenleme, öz değerlendirme ve öz yönetim", sosyal ve kültürlerarası beceriler "sosyal etkileşim, kültürel özellikler, kültürlerarasılık", verimlilik ve hesap verebilirlik "hedefleri belirleme, zamanlama, etik çalışma", liderlik ve sorumluluk "öncülük etme, sorumluluk alma, sorumlu davranma" anahtar ifadeleriyle kodlanmıştır. Öğrenme ve yenilikçilik becerileri tespit edilirken yaratıcılık "zekice fikirler üretme, yaratıcı yollar üretme”, eleştirel düşünme " fikirler arası bağlantıları anlama, problem çözme, analiz", iletişim ve iş birliği "takım hâlinde çalışma, başkalarının öğrenmesine katkıda bulunma, başkalarından öğrenme" anahtar ifadelerinden yararlanılmıştır. Bilgi, medya ve teknoloji becerilerine ilişkin kazanımlar bilgi okuryazarlığı boyutunda "bilgiye ihtiyaç duyma, bilgiyi bulma", medya okuryazarlığı boyutunda "görsel, işitsel, basılı mesajlara erişme ve çözümleme", bilgi ve iletişim teknolojileri (BİT) okuryazarlığı boyutunda "yeni teknolojileri ve teknolojik kavramları öğrenme, kullanma; internet üzerinden alışveriş, e-devlet gibi işlemleri yapma" anahtar kelimeleriyle tespit edilmiştir.

\section{Birinci amaca ilișkin bulgular}

Araştırmanın birinci alt amacı kapsamında 21. yüzyıl yaşam ve kariyer becerilerinin MEB'de (2020) yer alan dinleme/izleme, sözlü etkileșim, sözlü üretim, okuma ve yazma kazanımlarda yer alma oranları Tablo 1'de sunulmuştur. 
Tablo 1.

MEB'de (2020) 21. yüzyıl yaşam ve kariyer becerilerinin dağılımı

\begin{tabular}{|c|c|c|c|c|c|c|c|c|c|c|c|c|c|c|c|c|c|c|c|c|c|c|c|c|c|c|}
\hline 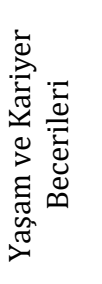 & & & 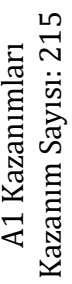 & & & & & 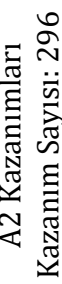 & & & & & 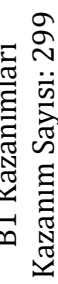 & & & & & 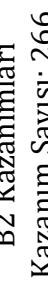 & & & & & 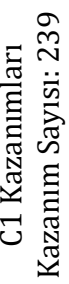 & & & 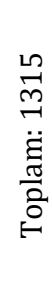 \\
\hline & 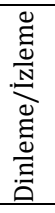 & 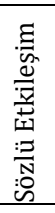 & 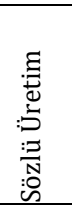 & 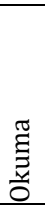 & $\begin{array}{l}\underset{\pi}{\tilde{N}} \\
\underset{\pi}{\pi}\end{array}$ & 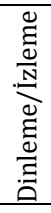 & 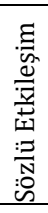 & 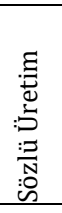 & 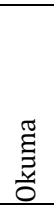 & జ్ల్ల & 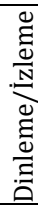 & 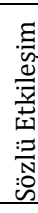 & 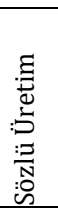 & 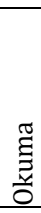 & $\tilde{\varepsilon}$ & $\frac{1}{5}$ & 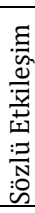 & 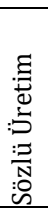 & 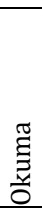 & $\underset{\tilde{N}}{\mathbb{N}}$ & 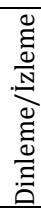 & 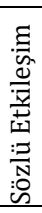 & 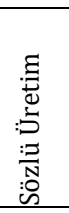 & $\begin{array}{l}\frac{\pi}{g} \\
\frac{\vec{z}}{0} \\
\end{array}$ & 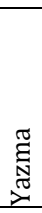 & \\
\hline 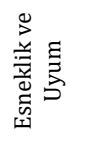 & 0 & 0 & 0 & 0 & 0 & 0 & 0 & 0 & 0 & 0 & 0 & 0 & 0 & 0 & 0 & ( & 0 & 0 & 0 & 0 & 0 & 0 & 0 & 0 & 0 & 0 \\
\hline 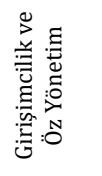 & 1 & 0 & 1 & 1 & 1 & 1 & 0 & 1 & 0 & 0 & 1 & 0 & 1 & 0 & 1 & 1 & 0 & 1 & 1 & 2 & 1 & 0 & 2 & 1 & 1 & 20 \\
\hline 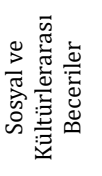 & 0 & 9 & 0 & 0 & 0 & 0 & 9 & 2 & 1 & 0 & 2 & 13 & 2 & 2 & 0 & 1 & 3 & 2 & 2 & 1 & 1 & 5 & 1 & 1 & 0 & 57 \\
\hline 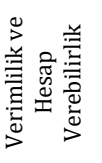 & 1 & 0 & 1 & 1 & 1 & 1 & 0 & 1 & 0 & 0 & 1 & 0 & 1 & 0 & 1 & 1 & 0 & 1 & 1 & 1 & 1 & 0 & 1 & 1 & 1 & 17 \\
\hline 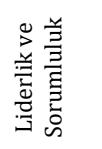 & 0 & 0 & 0 & 0 & 0 & 0 & 0 & 0 & 0 & 0 & 0 & 0 & 0 & 0 & 0 & 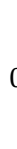 & 0 & 1 & 0 & 1 & 0 & 1 & 1 & 0 & 1 & 5 \\
\hline
\end{tabular}

$\underset{\substack{\frac{\pi}{2} \\ \frac{0}{0}}}{\stackrel{E}{2}}$

Tablo 1 incelendiğinde öğretim programındaki 1315 kazanımda yaşam ve kariyer becerilerine 99 kez ver verildiği gözlemlenmiştir. Bu becerilere ilişkin alt başlıklarda esneklik ve uyum becerilerinin yer almadığı, girişimcilik ve özyönetimin 20 frekansla, sosyal ve kültürlerarası becerilerin 57 frekansla, verimlilik ve hesap verebilirliğin 17 frekansla, liderlik ve sorumluluğun 5 frekansla temsil edildiği gözlemlenmiştir.

Öğretim programında "girişimcilik ve özyönetim" becerisinin A1 seviyesinde 5, A2 seviyesinde 2, B1 seviyesinde 3, B2 seviyesinde 5 ve $\mathrm{C} 1$ seviyesinde 5 frekansla yer aldığı tespit edilmiştir.

A1 seviyesinde "A1.SÜ.25. Konuşma amacına uygun strateji, yöntem ve teknikleri kullanır." kazanımı öğrencilerin kendi konuşma süreçlerini yönetme ve düzenlemeye yönelik olduğu için öz yönetim becerisini yansıtmaktadır (MEB, 2020, s. 35).

A2 seviyesinde ise "A2.D.60. Dinleme amacına uygun strateji, yöntem ve teknikleri kullanır." kazanımı öz yönetim becerisini bir önceki örneğe benzer şekilde dinleme/izleme boyutunda temsil etmektedir (MEB, 2020, s. 41).

Program, sarmal bir yaklaşımla hazırlandığı için dil becerilerine yönelik strateji, yöntem ve teknik kullanımına ilişkin kazanımlar bütün seviyelerde karşımıza çıkmaktadır. Farklı seviyelerdeki bu kazanımlar girişimcilik ve özyönetim becerisi altında kodlanmıştır. Ancak C1 seviyesindeki "C1.SÜ.29. Kendi konuşmasını/başkalarının konuşmalarını içerik, anlatım, sunum ve beden dili açısından değerlendirir." kazanımı öğrencilerin özyönetim becerisinin öz değerlendirme boyutunu yansıtan bir kazanım olarak karşımıza çıkmaktadır (MEB, 2020, s. 68).

Programda en sık yer verilen yaşam ve kariyer becerisi 57 frekans değeri ile "sosyal ve kültürlerarası" becerilerdir. Frekans değerlerinin düzeylere göre dağılımı da A1 seviyesi 9, A2 seviyesi 12, B1 seviyesi 19, B2 seviyesi 9 ve C1 seviyesi 8 olarak karşımıza çıkmaktadır. Tablo incelendiğinde bütün seviyelerde sosyal ve kültürlerarası becerilerin dağılımının "sözlü etkileşim" dil becerisi üzerinde yoğunlaştığı gözlemlenmektedir. Ancak diğer dil becerilerinde düşük oranla da olsa temsil edildiği ifade edilebilir.

A1 seviyesinde "A1.SE.9. Hobilerine/ilgi alanlarına iliş̧in diyaloglar kurar." kazanımı öğrencilerin hobilerini ve ilgi alanlarını birbirleriyle paylaşmalarından dolayı "sosyal etkileşim" bağlamına uygun olduğu görülmektedir (MEB, 2020, s. 34). 
A2 seviyesinde "A2.SE.19. Kültürel bağlamlara (gelenekler, kutlama, davet, tebrik, teşekkür, temenni, bayram, taziye, anma vb.) uygun kalıp ifadeleri kullanarak diyaloglara katılır.” kazanımının farklı kültürlere ilişkin unsurların paylaşılması açısından "kültürlerarası becerileri” temsil ettiği ifade edilebilir (MEB, 2020, s. 42).

B1 seviyesinde “B1.O.42. Metinde geçen kültürel özelliklere ilişkin bilgileri belirler.” kazanımı okuma becerisindeki “kültürel özellikleri” anahtar ifadesiyle belirlenerek "kültürlerarası beceriler” kapsamında kabul edilmektedir (MEB, 2020, s. 54).

B2 seviyesinde “B2.Y.3. Kültürel bağlama uygun kutlama ve tebrik mesajları/metinleri yazar.” kazanımı yazma becerisinde öğrencilerin kültürel ifadeleri kullanmasına dönük bir kültürlerarası beceri olarak karşımıza çıkmaktadır (MEB, 2020, s. 64).

C1 seviyesinde “C1.SE.22. Kamu, iş veya eğitim alanında çeşitli sorunlara ilişkin tartışmalara katılır.” kazanımı "sosyal etkileşim” boyutunda değerlendirilmektedir (MEB, 2020, s. 67).

Diğer yandan aynı düzeyde "C1.SÜ.24. Kültürel bir öge/gelenek veya mekân hakkında konuşmalar yapar." şeklinde ifade edilen sözlü üretim kazanımı aynı becerinin "kültürlerarasılık” boyutuna hitap etmektedir (MEB, 2020, s. 68).

Öğretim programında yaşam ve kariyer becerilerinden "verimlilik ve hesap verebilirlik" boyutuna 17 frekansla yer verildiği tespit edilmiștir. Bu frekansların düzeylere göre dağllımı A1 seviyesinde 4, A2 seviyesinde 2, B1 seviyesinde 3, B2 seviyesinde 4, C1 seviyesinde 4 olarak görülmektedir.

A1 seviyesinde “A1.SÜ.24. Konuşma amacını belirler." sözlü üretim kazanımının "hedefleri belirleme” anahtar ifadesiyle ilişkili olup verimlilik kavramına dönük olduğu ifade edilebilir (MEB, 2020, s. 35).

A2 düzeyinde "A2.D.59. Dinleme amacını belirler." dinleme kazanımında da verimlilik becerisine yönelik "hedef belirleme" davranışından söz etmek mümkündür (MEB, 2020, s. 41).

21. yüzyll yaşam ve kariyer becerilerinden verimlilik ve hesap verebilirlik ile ilgili programda yer alan diğer kazanımlar da "hedef belirleme" boyutuyla ilişkilidir. Buna karşılık öğretim programında becerinin hesap verebilirlik boyutuyla ilgili kazanımlara rastlanmamıştır. Diğer yandan verimlilik boyutunun "zamanlama" ve "etik çalışma" kavramlarına ilişkin kazanımlara da yer verilmediği gözlemlenmiştir.

Araştırmanın birinci alt probleminde ele alınan son başlık liderlik ve sorumluluk becerisidir. Programda bu beceriye 5 frekansla düşük düzeyde yer verildiği görülmektedir. Diğer yandan programda alt düzeylerde bu beceriye ilişkin kazanımların yer almadığı ve sadece $\mathrm{B} 2$ ve $\mathrm{C} 1$ düzeylerinde tespit edildiği görülmektedir.

B2 seviyesinde "B2.SÜ.38. Grup çalışmalarında konuşulanların özetini sunar." sözlü üretim kazanımında öğrencinin bulunduğu grupta sorumluluk alarak grup lideri gibi özet sunma davranışı "liderlik ve sorumluluk" becerisine atıfta bulunulmaktadır (MEB, 2020, s. 61).

C1 düzeyinde “C1.SE.6. Bir tartışmaya, uygun soru ve yönlendirmelerle başkalarının da katılımını sağlar.” sözlü etkileşim kazanımı diğer kişilerin katılımını sağlama boyutuyla "liderlik" becerilerini ön plana çıkarmaktadır (MEB, 2020, s. 67).

İkinci amaca ilişskin bulgular

Araştırmanın ikinci alt amacında 21. yüzyıl öğrenme ve yenilikçilik becerilerinin MEB'de (2020) yer alan dinleme/izleme, sözlü etkileşim, sözlü üretim, okuma ve yazma kazanımlarda yer alma oranları Tablo 2'de verilmiştir.

Tablo 2.

MEB'de (2020) 21. yüzyıl öğrenme ve yenilikçilik becerilerinin dağılımı

\begin{tabular}{|c|c|c|c|c|c|c|c|c|c|c|c|c|c|c|c|c|c|c|c|c|c|c|c|c|c|c|}
\hline \multirow{2}{*}{\multicolumn{2}{|c|}{ 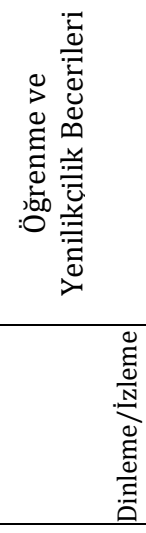 }} & & 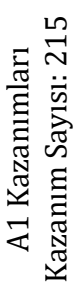 & & & & & 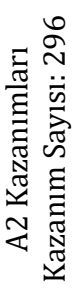 & & & & & 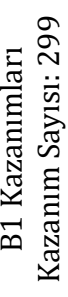 & & & & & 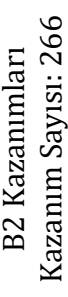 & & & & & 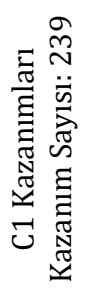 & & & 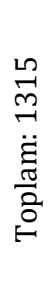 \\
\hline & & 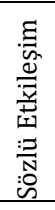 & 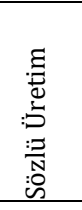 & 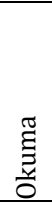 & 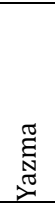 & 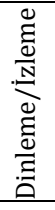 & 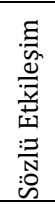 & 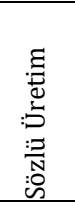 & 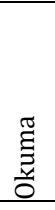 & 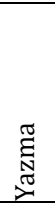 & 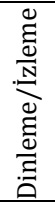 & 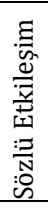 & 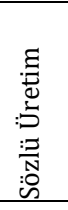 & 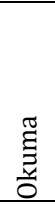 & $\begin{array}{l}\text { đ్̃ } \\
\text { त्र }\end{array}$ & 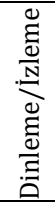 & 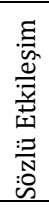 & 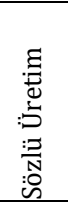 & 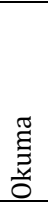 & 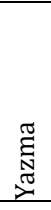 & 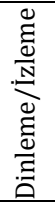 & 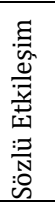 & 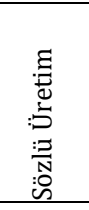 & 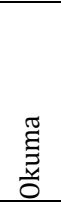 & 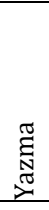 & \\
\hline $\begin{array}{l}\overline{\bar{U}} \\
\overline{\bar{N}} \\
\bar{N}\end{array}$ & 0 & 0 & 0 & 0 & 0 & 0 & 0 & 1 & 0 & 0 & 0 & 0 & 1 & 0 & 0 & 0 & 0 & 1 & 1 & 1 & 0 & 0 & 2 & 0 & 2 & 9 \\
\hline
\end{tabular}




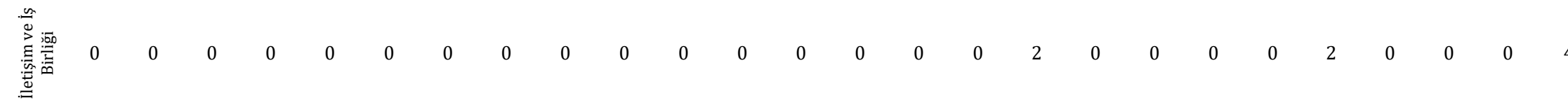

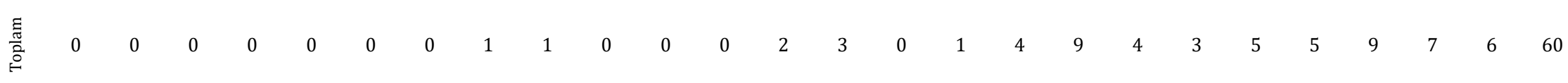

Tablo 2 incelendiğinde öğretim programındaki dil becerilerine ilişkin kazanımlarda öğrenme ve yenilikçilik becerilerine 60 kez ver verildiği gözlemlenmektedir. Bu becerilere ilişkin alt başlıklarda yaratıcıllk becerileri 9 frekansla, eleştirel düşünme 47 frekansla, iletişim ve iş birliği becerileri 4 frekansla temsil edilmektedir.

Öğretim programında yaratıcılık becerilerine A1 seviyesinde yer verilmemiștir. A2 düzeyinde 1 frekans, B1 düzeyinde 1 frekans, B2 düzeyinde 3 frekans, C1 düzeyinde ise 4 frekansla temsil edildiği gözlemlenmektedir.

A2 seviyesindeki "A2.SÜ.30. Hazırlıksız konuşmalar yapar." sözlü üretim kazanımında hazırlıksız konuşma yapmanın doğaçlamayla birlikte yaratıcılık becerilerine hitap ettiği ifade edilebilir (MEB, 2020, s. 43).

B2 düzeyindeki "B2.0.60. Metnin içeriğine ilişkin tahminlerde bulunur.” okuma kazanımının öğrencinin hayal gücüne ve zekice fikirler üretmesine dönük olduğu söylenebilir (MEB, 2020, s. 63).

C1 seviyesindeki "C1.SÜ.14. Plan/tasarı/hayallerini uygun ifadeleri kullanarak anlatır.” Sözlü üretim kazanımı öğrencilerin hayal güçlerini yansıtmaları tarafından yaratıcılık becerisiyle ilgilidir. Aynı düzeydeki "C1.Y.10. Kurmaca metinler yazar." kazanımı öğrencilerin zekice fikirler üreterek yaratıcllık becerilerini geliştirmeye yönelik yazma etkinliklerini kapsamaktadır (MEB, 2020, s. 68).

Tablo 1 ele alındığında öğrenme ve yenilikçilik becerilerinden öğretim programında en sık temas edilen becerinin 47 frekansla eleştirel düşünme olduğu gözlemlenmektedir. Eleștirel düşünme becerisine programda A1 düzeyinde rastlanmamıştır. Buna karşıllk A2 düzeyinde 1, B1 düzeyinde 4, B2 düzeyinde 16, C1 düzeyinde 26 frekansla temsil edildiği görülmektedir.

A2 düzeyindeki "A2.0.56. Temel bağdaşıklık ögelerinin anlama etkisini fark eder." okuma kazanımının fikirler arasındaki bağlantıları anlama açısından eleştirel düşünme becerisini yansıttığı söylenebilir (MEB, 2020, s. 46).

B1 seviyesindeki “B1.SÜ.50. Bir sorunun çözümüne yönelik konuşmalar yapar.” sözlü üretim kazanımı problem çözmeyi içerdiği için eleştirel düşünme becerisini yansıtmaktadır (MEB, 2020, s. 53).

B2 düzeyindeki "B2.0.10. Aynı konuda yazılmış metinleri içerik açısından karşılaştırır." okuma kazanımında farklı metinlerin analizi içeren eleştirel düşünme becerisini içermektedir (MEB, 2020, s. 62).

C1 seviyesindeki "C1.Y.32. Bilimsel ifade ve kalıpları kullanarak tartışmacı metinler yazar.” yazma kazanımı fikirler arasındaki bağlantıları kurma ve problem çözme süreçlerini içerdiği için eleştirel düşünme becerisiyle ilgilidir (MEB, 2020, s. 71).

Öğretim programında öğrenme ve yenilikçilik becerilerinden en az temsil edilen 4 frekansla iletişim ve iş birliği becerisidir. Bu beceri öğretim programında sadece B2 ve C1 düzeylerinde ikişer frekansla yer almaktadır.

B2 seviyesindeki "B2.SE.43. Farklı bakış açılarına yer vererek konuşmalara katılır.” sözlü etkileşim kazanımında öğrencinin ortaya koyduğu farklı bakış açılarıyla başkalarının öğrenmesine katkıda bulunduğu ifade edilebilir (MEB, 2020, s. 60).

C1 düzeyinde yer alan "C1.SE.11. İlgi ve ihtiyaçlarına yönelik akademik bilgi alışverişinde bulunur." sözlü etkileşim kazanımı öğrencilerin bilgi alışverişi aracılığıyla iş birliğine yöneliktir (MEB, 2020, s. 67).

Üçüncü amaca ilişskin bulgular

Araştırmanın üçüncü alt amacında 21. yüzyıl bilgi, medya ve teknoloji becerilerinin MEB'de (2020) yer alan dinleme/izleme, sözlü etkileşim, sözlü üretim, okuma ve yazma kazanımlarda yer alma oranları Tablo 3'te gösterilmiştir.

Tablo 3.

MEB'de (2020) 21. yüzyıl bilgi, medya ve teknoloji becerilerinin dağı̆lımı

\begin{tabular}{|c|c|c|c|c|c|c|c|c|c|c|c|c|c|c|c|c|c|c|c|c|c|c|c|c|c|c|}
\hline \multirow[t]{2}{*}{ 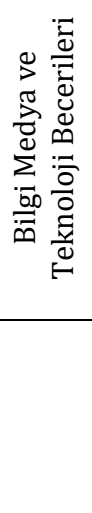 } & & & 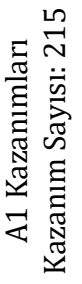 & & & & & 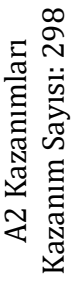 & & & & & 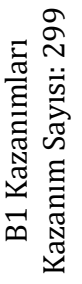 & & & & & 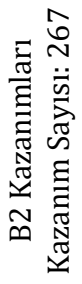 & & & & & 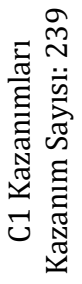 & & & 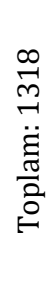 \\
\hline & 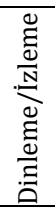 & 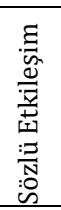 & 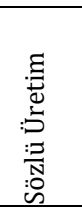 & 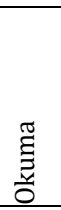 & 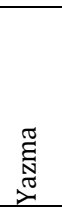 & 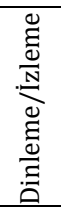 & 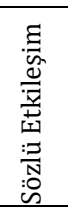 & 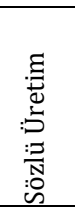 & $\begin{array}{l}\text { 节 } \\
\text { 竘 } \\
\end{array}$ & 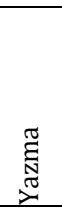 & 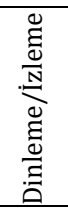 & 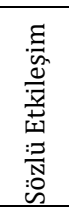 & 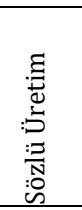 & $\begin{array}{l}\frac{\pi}{\Xi} \\
\frac{\vec{z}}{0} \\
\end{array}$ & $\begin{array}{l}\underset{\pi}{\tilde{N}} \\
\underset{\pi}{\pi} \\
\end{array}$ & 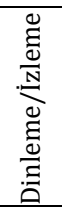 & 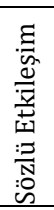 & 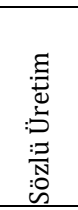 & $\stackrel{\widetilde{g}}{\Xi}$ & 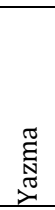 & 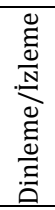 & 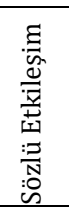 & 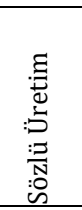 & $\begin{array}{l}\frac{\pi}{g} \\
\frac{\bar{g}}{0} \\
\end{array}$ & 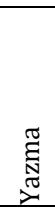 & \\
\hline
\end{tabular}




\begin{tabular}{|c|c|c|c|c|c|c|c|c|c|c|c|c|c|c|c|c|c|c|c|c|c|c|c|c|c|c|}
\hline 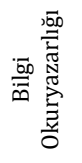 & 2 & 0 & 0 & 6 & 0 & 11 & 0 & 0 & 7 & 0 & 1 & 0 & 0 & 1 & 0 & 0 & 1 & 0 & 2 & 0 & 2 & 0 & 0 & 3 & 1 & 37 \\
\hline 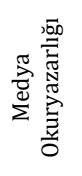 & 0 & 0 & 1 & 1 & 1 & 3 & 0 & 0 & 4 & 3 & 6 & 0 & 1 & 7 & 5 & 4 & 1 & 1 & 4 & 4 & 5 & 1 & 1 & 3 & 4 & 60 \\
\hline 点空 & 0 & 0 & 0 & 0 & 0 & 1 & 1 & 0 & 1 & 1 & 0 & 0 & 0 & 1 & 1 & 1 & 2 & 1 & 3 & 1 & 1 & 1 & 0 & 1 & 1 & 18 \\
\hline
\end{tabular}

Tablo 3 incelendiğinde öğretim programındaki dil becerilerine ilişkin kazanımlarda bilgi, medya ve teknoloji becerilerinin 115 kez yer aldığı gözlemlenmektedir. Bu veri öğretim programında en fazla bilgi, medya ve teknoloji becerilerinin yer aldığını göstermektedir. Alt boyutlar açısından programda bilgi okuryazarlığının 37 frekansla, medya okuryazarlığının 60 frekansla, BíT okuryazarlığının 18 frekansla temsil edildiği görülmektedir.

Öğretim programında bilgi okuryazarlığı becerilerine A1 seviyesinde 8 kez, A2 seviyesinde 18 kez, B1 seviyesinde 2 kez, B2 seviyesinde $3 \mathrm{kez}$, C1 seviyesinde 6 kez yer verildiği gözlemlenmektedir.

A1 seviyesindeki "A1.0.21. Metinden konum bildiren basit ifadeleri seçer." okuma kazanımı metinde ihtiyaç duyulan bir bilgiyi bulmaya yönelik bilgi okuryazarlı̆̆ becerisine hitap etmektedir (MEB, 2020, s. 36).

A2 düzeyindeki “A2.D.25. Seyahat ve konaklamaya ilişkin bilgileri seçer.” dinleme/izleme kazanımı dinlenilen bir metinden özel bir bilgiyi seçmeye dönük bilgi okuryazarlı̆̆ı becerisiyle ilgilidir (MEB, 2020, s. 40).

B1 seviyesinde yer alan “B1.D.63. Dinlediklerinden/izlediklerinden istenilen bilgileri seçer.” dinleme/izleme kazanımının bilgiyi bulmaya hizmet ettiği görülmektedir (MEB, 2020, s. 50).

B2 düzeyindeki “B2.SE.11. İhtiyacı olan herhangi bir konuda ayrıntılı bilgi ve açıklama ister.” sözlü etkileşim kazanımının ihtiyaç duyulan bilgiye ulaşmayı yansıttığı söylenebilir (MEB, 2020, s. 60).

C1 seviyesinde "C1.0.46. Okuduklarını anlamak için başvuru kaynaklarını kullanır." okuma kazanımında ihtiyaç duyduğu ek bilgiye nasıl ulaşacağını bilme durumu bilgi okuryazarlığı ile ilgilidir (MEB, 2020, s. 70).

Programda 60 frekansla yer verilen medya okuryazarlı̆̆ becerisine A1 seviyesinde 3 kez, A2 seviyesinde 10 kez, B1 seviyesinde 19, B2 seviyesinde 14, C1 seviyesinde 14 kez yer verildiği görülmektedir.

A1 seviyesindeki “A1.SÜ.28. Afiş, bilet, broşür, ilan, menü vb. metinlerdeki temel bilgileri anlatır.” sözlü üretim kazanımında görsel ve basılı bir mesajı ifade etme becerisini gözlemlemek mümkündür (MEB, 2020, s. 35).

A2 düzeyindeki “A2.D.13. İletişim araçlarındaki soru ve yönergeleri takip eder.” dinleme/izleme kazanımı görsel işitsel araçlardaki bilgileri anlamlandırmayla ilgilidir (MEB, 2020, s. 40).

B1 seviyesindeki “B1.SÜ.20. Harita, kroki, grafik, tablo, zaman çizelgesi vb. görsellerden hareketle sunum yapar." sözlü üretim kazanımı görsel ürünleri anlama ve ifade etme becerilerini içermektedir (MEB, 2020, s. 52).

B2 seviyesinde yer verilen “B2.0.15. Görsellerle oluşturulmuş bir metindeki iletileri belirler.” okuma kazanımı görsel mesajları anlamlandırmaya yöneliktir (MEB, 2020, s. 62).

C1 düzeyindeki “C1.Y.36. Afiş veya broşür benzeri metinler hazırlar.” yazma kazanımı görseller içeren metinler oluşturma içerdiği için medya okuryazarlı̆̆ı ile ilgilidir (MEB, 2020, s. 71).

Tablo 3'e göre öğretim programında 18 kez yer verilen BİT okuryazarlığı becerisine A1 düzeyinde rastlanmamaktadır. Beceri A2 seviyesinde 4 frekansla, B1 düzeyinde 2 frekansla, B2 düzeyinde 8 frekansla, C1 düzeyinde 4 frekansla temsil edilmektedir.

A2 seviyesindeki "A2.0.16. Bilgisayar vb. teknolojik araçlardaki yönerge ve bildirimleri anlar." okuma kazanımı teknolojik araçlardaki ifadeleri anlamaya yöneliktir (MEB, 2020, s. 45).

B1 seviyesinde yer alan “B1.0.65. Teknolojiyle ilgili söz varlı̆̆ını belirler.” okuma kazanımının teknolojik ifadeleri öğrenmeye yönelik beceriye hitap ettiği görülmektedir (MEB, 2020, s. 55).

B2 düzeyindeki “B2.Y.64. Yazılarında teknolojiyle ilgili söz varlığını kullanır.” yazma kazanımı öğrenilen teknolojik kavramları ifade etmeyi kapsamaktadır (MEB, 2020, s. 65). 
C1 seviyesinde ise "C1.SE.33. Çevrim içi ortamlarda bağlama uygun konuşmalara katılır.” sözlü etkileşim kazanımı teknolojiyi kullanmaya hizmet etmektedir.

\section{SONUÇ VE ÖNERILER}

2020 yılında Millı̂ Eğitim Bakanlı̆̆ı tarafından hazırlanan Türkçenin Yabancı Dil Olarak Öğretimi Programı́na ait kazanımların P21 becerileri çerçevesine uygunluğunun incelendiği bu çalışmada toplam 1315 kazanım çerçevede bulunan 3 ana başlığa (Yaşam ve Kariyer Becerileri; Öğrenme ve Yenilikçilik Becerileri; Bilgi, Medya ve Teknoloji Becerileri) göre incelenmiştir. Yapılan içerik analizi sonucunda 1315 kazanım arasında "Yaşam ve Kariyer Becerilerine" 99; "Öğrenme ve Yenilikçilik Becerilerine" 60; "Bilgi, Medya ve Teknoloji Becerilerine" 115 kez yer verildiği gözlemlenmiştir. Buradan hareketle programdaki toplam kazanım sayısı düşünüldügünde 21. yüzyll becerilerinin temsil gücünün düşük düzeyde olduğu ifade edilebilir. "Öğrenme ve Yenilikçilik Becerilerine" ait kazanımların çağın gereklilikleri ile ilişkili, bilgiye erişme ve bilgi toplumu olma yolundaki önemli adımı olan yeni bilgiye ulaşma noktasında düşük oranda temsili söz konusudur. Aynı zamanda becerilerin boyutlara, düzeylere ve kazanımlara ilişkin dağılımının düzensiz olduğu söylenebilir. Ortaya koyulan bu çalışma Kurudayığlu ve Soysal'ın (2019) Türkçe dersi öğretim programını 21. yüzyll becerileri kapsamında ele aldıkları incelemede "21. yüzyıl becerilerinin göz önünde bulundurulmadığı, becerilerin kazanımlara dağılımında herhangi bir dengenin gözetilmediği" şeklindeki yorumuyla aynı doğrultudadır (s. 491).

Üniversiteler bünyesindeki Türkçe Öğretim Merkezleri öğrencilerin yeni bir dili öğrendikleri ya da bildikleri dillerin gelişmişlik düzeyini artırmak amacıyla öğretim gördükleri yerlerdir. Gerçekleştirilen incelemede "Yaşam ve Kariyer Becerileri" ana başlı̆̆ altında bulunan "Esneklik ve Uyum Yeteneği" alt başlığına ait kazanımlara A1-C1 seviyeleri arasında hiç yer verilmediği belirlenmiştir. Bu anlamda öğrencilerin yeni geldikleri öğrenme ortamlarına karş̧ açık ve esnek olmaları ile süreç içerisinde uyum becerilerini etkin kullanmalarını gerektiren beceriler son derece önemlidir. Öğretim programında bu beceriye yer verilmemiş olması bir eksiklik olarak değerlendirilebilir. Bu veri, Demir ve Özyurt'un (2021) 2019-2020 eğitim öğretim yılında Türkiye'de uygulanmakta olan Sosyal Bilgiler Dersi Öğretim Programının kazanımları ile ders kitabında yer alan etkinlik ve soruları 21. yüzyıl becerileri bağlamında inceledikleri çalışmada geçen: "Programda ve kitaplarda 21. yüzyıl becerilerinden esneklik ve uyum becerilerinin geliştirilmesine yönelik kazanım, etkinlik ve soruların yer almadığı tespit edilmiştir." şeklindeki açıklamaları ile benzerlik göstermektedir (s. 1259). Aynı ana başlık altındaki "Girişimcilik ve Öz Yönetim” alt başlığına ait kazanımların programda düşük düzeyde bir frekans ile temsil edildiği ortaya çıkmakta ve bu durum bir eksiklik olarak görülmektedir. Öz yönetim bireylerin kendi davranışları hakkındaki yorumları ve düzeltmelerini ifade eder. Öte yandan yüksek düzey düşünme becerileri içindeki üstbiliş kavramı ile ilişkilidir. Üstbilişsel düşünme, öğrencilerin hatalarını ya da düzeltmek istedikleri yönelimlerini belirli ölçütlere göre daha etkili olarak şekillendirmelerinde önemli bir noktayı oluşturur. Bu anlamda bu becerilere öğretim programındaki kazanımlar nezdinde daha fazla yer verilmesi gerekmektedir. Yine programda "Liderlik ve Sorumluluk" alt başlığı ile ilgili yer verilen kazanımların yetersizliği dikkati çekmektedir. "Sosyal ve Kültürlerarası Beceriler" alt başlığı programda temsil edilen mevcut kazanımlar içerisinde daha fazla değinilen bir yapıdadır ve bu durum dil öğretiminde iletişimsel yaklaşım ile daha koşut bir özellik taşımaktadır. Bu durum hâlihazırda olumlu bir özellik olarak değerlendirilmenin yanı sıra kazanım sayıları içerisindeki oranının artması faydalı olacaktır. "Verimlilik ve Hesap Verebilirlik" alt boyutunda programda verimlilik ile ilgili kazanımların yer almasının yanında hesap verebilirlik ile ilgili kazanımların görece eksik olduğu sonucuna ulaşılmıştır.

Araştırmada "Öğrenme ve Yenilikçilik Becerileri” ana başlı̆̆ındaki alt başlık "Yaratıcılık” ile ilgili bütün dil öğretim seviyelerinde sadece 9 kazanıma yer verilmesi bir eksiklik olarak değerlendirilebilir. Günümüzde yaratıcı düşünme ve buna bağlı olarak ortaya çıkan gelişmeler göz önüne alındığında programda bu alt başlık ile ilgili kazanımların daha fazla yer tutması faydalı olacaktır. "Eleştirel Düşünme" alt başlı̆̆ında programdaki kazanım sayıları yetersiz olmakla birlikte diğer alt başlıklara göre daha yüksek düzeyde bir orana sahip olduğu görülmektedir. Bu durum öğrencilerin sorgulama becerilerinin gelişimi adına olumlu bir özelliktir. Normal bir şekilde dil öğretim seviyelerinin daha ileri aşamalarında daha fazla kazanım ile temsil edilen bu beceri, dil yeterliklerinin üst düzeye çıkmasıyla artan yapısı arasında anlamlı bir ilişki ortaya koymaktadır. "İletişim" ve "İş birliği" alt başlıklarında ise programdaki kazanım sayısı oldukça yetersiz kalmaktadır. Çalışma, Erdamar ve Barası'nın (2021) 2018 yılı Ortaokul Türkçe Dersi Öğretim Programı'nı 21. yüzyıl becerileri açısından inceledikleri araştırmada iş birliğinin kazanımlar içerisinde az sayıda temsil edildiği yönündeki tespitleri ile aynı doğrultudadır (s. 312). Dil öğretiminde özellikle üzerinde durulması gereken bir yapı oluşturan iletişimsel becerilere ve bu becerinin bir getirisi olan iş birliğine daha fazla önem verilmesi öğrencilerin dil öğrenme süreçlerini geliştirmesi açısından etkili olacaktır.

"Bilgi, Medya ve Teknoloji Becerileri” başlığında bulunan “Bilgi Okuryazarlı̆̆ı" alt başlığı programda yetersiz bir kazanım sayısına sahiptir. Günümüz şartları göz önüne alındığında bilgi, bilgiye ulaşma ve bilgiyi etkili, planlı kullanma gibi birçok üst düzey beceriyi işletmeyi gerektiren bu beceri programda ileri dil seviyelerinde daha az sayıda karşılık bulmuştur. İleri seviye dil becerileri kapsamında bu beceriye ait kazanımların artırılması ve işlevsel hale getirilmesi faydalı olacaktır. "Medya Okuryazarlığı” alt başlı̆̆ı günümüz dijital dünyasında önemli becerilerden bir tanesidir. Bu alt başlık ile ilgili kazanımlar programda önemli bir oranı temsil etmektedir. Bu özellik 21. yüzyıl becerileri açısından ele alındı̆̆ında olumlu olarak değerlendirilmektedir. "Bilgi ve İletişim Teknolojileri Okuryazarlığı” öğretim programında az tekrar edilen bir kazanım sayısı ile karşımıza çıkmaktadır. Bu sonuç, Kalemkuş’un (2021) 2018 yılı Fen Bilimleri Dersi Öğretim Programı (FBDÖP) üçüncü ve dördüncü sınıflar kapsamında olan kazanımların 21. yüzyıl becerileri açısından incelendiği çalışmasında "21. yüzyıl becerilerinden olan ve günümüz bilgi toplumunda bireylerin ihtiyaç duyduğu becerilerden olan bilgi iletişim ve teknoloji okuryazarlı̆̆ı becerisine yönelik herhangi bir kazanım 
bulunmamaktadır" şeklindeki değerlendirmesi ile benzerlik göstermektedir. Teknolojik okuryazarlık ile de ilişkili olan bu beceri mobil araçları kullanmadan günlük hayatımızı kolaylaştıran birçok uygulamayı kullanmaya kadar genişleyen bir yelpazedeki becerileri içine almaktadır. Bu bakımdan ülkenin ihtiyaçlarına yönelik hazırlanan birçok mobil aracın ve uygulamanın kullanılmasına ilişkin uyumu yansıtan becerilerin öğretimi öğrenciler açısından olumlu sonuçlar doğuracaktır.

\section{KAYNAKÇA}

Atik, A. D. ve Yetkiner, A. (2021). Ortaöğretim biyoloji dersi öğretim programı kazanımlarının 21. yüzyıl becerileri açısından incelenmesi. Trakya Eğitim Dergisi, 11(2), 745-765.

Aydemir, H., Karalı, Y., Coşanay, G. (2020). Sosyal bilgiler öğretmen adaylarının 21. yüzyıl öğreten ve öğrenen becerilerinin incelenmesi. USBAD Uluslararası Sosyal Bilimler Akademi Dergisi 2(4), 1199-1214.

Battelle for Kids. (2019). Networks. http://www.battelleforkids.org/networks/ edleader21 network

Benek, İ. (2019). Sosyobilimsel stem etkinliklerinin öğrencilerin tutumlarına ve 21. yüzyll becerilerine etkisinin incelenmesi. Yayımlanmamış doktora tezi, İstanbul Üniversitesi Cerrahpaşa Matematik ve Fen Bilimleri Eğitimi Anabilim Dalı, İstanbul.

Bozkurt, F. (2021). 21. yüzyıl becerileri açısından sosyal bilgiler öğretmenliği lisans programının değerlendirilmesi. Pamukkale Üniversitesi Eğitim Fakültesi Dergisi, 51, 34-64. doi:10.9779/pauefd.688622

Çevik, A. \& Demirtaş, H. (2021). Okul müdürleri ve öğretmenlerin bakış açısıyla okul müdürlerinin 21. yüzyıl becerileri. İönü Üniversitesi Eğitim Fakültesi Dergisi, 22(2), 1512-1543. DOI: 10.17679/inuefd.960126

Demir, A. Y. \& Özyurt, M. (2021). Sosyal bilgiler dersi öğretim programı ve ders kitaplarının 21. yüzyıl becerileri bağlamında incelenmesi. İnönü Üniversitesi Eğitim Fakültesi Dergisi, 22(2), 1254-1290. DOI: 10.17679/inuefd.867905

Devrani, A. E. P. (2021). Gençler için 21. yüzyıl becerileri ve dijitalleşen dünyanın gereklilikleri: Yeni okuryazarlıklar. Gençlik Araştırmaları Dergisi, 9(24), 5-24.

Engin, A. O. ve Korucuk, M. (2021). Öğrencilerin 21. yüzyıl becerilerinin çeşitli değişkenler açısından incelenmesi. Gazi Üniversitesi Gazi Eğitim Fakültesi Dergisi, 41(2), 1081- 1119.

Erdamar, G. \& Barası, M. (2021). 21. yüzyıl becerileri açısından ortaokul Türkçe dersi öğretim programı. TEBD, 19(1), 312-342. https://doi.org/10.37217/tebd.868788

European Parliament and The Council. (2006). Key Competences for Lifelong Learning-A European Reference Framework. Brüksel: Official Journal of the European Union.

Gelmez Burakgazi, S. Karsantık, Y., Aktan, T, Ayaz, M. A, Büge, C. B. Karataş, F. Sinem Ödün, S. Şanlı, Ş. V. Tarım, B. ve Yavaşca, O. (2019) Equipped or not? Investigating pre-service teachers' 21st century skills. Asia Pacific Journal of Education, (39)4, 451468.

Gürültü, E., Aslan, M., ve Alcı, B. (2020). Ortaöğretim öğretmenlerinin 21. yüzyıl becerileri kullanım yeterlikleri. Hacettepe Üniversitesi Eğitim Fakültesi Dergisi, 35(4), 780-798. doi: 10.16986/HUJE.2019051590

Işıkgöz, M. E. (2021). Ortaokul beden eğitimi ve spor dersi öğretim programı kazanımlarının 21. yüzyıl becerileri açısından incelenmesi, Artuklu Insan ve Toplum Bilim Dergisi 6 (1), 71-84.

Kalemkuş, J. (2021). Fen bilimleri dersi öğretim programı kazanımlarının 21.yüzyıl becerileri açısından incelenmesi. Anadolu Journal of Educational Sciences International, 11(1), 63-87. DOI: 10.18039/ajesi.800552

Kurudayığlu, M. ve Soysal, T. (2019). 2018 Türkçe dersi öğretim programı kazanımlarının 21. yüzyıl becerileri açısından incelenmesi. Ahi Evran Üniversitesi Sosyal Bilimler Enstitüsü Dergisi, 5(2), 483-496.

Millî Eğitim Bakanlığı. (2018). Türkçe Dersi Öğretim Programı (İlkokul ve Ortaokul 1, 2, 3, 4, 5, 6, 7 ve 8. Sinıflar). Ankara: MEB.

Miles, M. B., Huberman, A. M. (1994). Qualitative data analysis: an expanded sourcebook. California: Sage Publications.

Millî Eğitim Bakanlığı. (2020). Türkçenin Yabancı Dil Olarak Öğretimi Programı. Ankara: MEB.

Özmutlu, A., ve Bayrak Özmutlu, E. (2021). Grafik tasarımı bölümü öğrenme çıktılarının 21. yüzyıl becerileri temelinde incelenmesi. Atatürk Üniversitesi Güzel Sanatlar Enstitüsü Dergisi, 27(46), 138-152. https://doi.org/10.35247/ataunigsed.844115

Partnership for 21st Century Skills (P21). (2003). Learning for the 21st century: A report and mile guide for 21st century skills. Retrieved from Washington, D.C.: https://files.eric.ed.gov/fulltext/ED480035.pdf

Pellegrino, J. W. \& Hilton, L. M. (2012). Education For Life And Work Developing Transferable Knowldege and Skills in the 21 st Century. National Research Council of the National Academics, Washington, D.C.: The National Academies Press. 
Selçuk, G. (2020). İlköğretim matematik öğretmeni adaylarının 21. yüzyıl becerilerine yönelik metaforik algıları. Celal Bayar Üniversitesi Sosyal Bilimler Dergisi, 18(04), 184-208.

Silva, E. (2009). Measuring skills for 21st century learning. The Phi Delta Kappan, 90(9), 630-634.

Tuğluk, M. N. \& Özkan, B. (2019). MEB 2013 okul öncesi eğitim programının 21. yüzyıl becerileri açısından analizi, Temel Eğitim Dergisi, 1(4), 29-38.

Uçak S., ve Erdem, H. H. (2020). Eğitimde yeni bir yön arayışı bağlamında "21. yüzyıl becerileri ve eğitim felsefesi". Uşak Üniversitesi Eğitim Araştırmaları Dergisi, 6(1), 76-93.

Yeni, G. (2020). 21. yüzyıl becerilerinin okul yöneticilerinin liderlik yönlerine olan etkisi. Uluslararası Liderlik Eğitimi Dergisi (ULED), 2(2), 19-30.

Yeniay Üsküplü, Z. D. (2019). Eğitim sosyolojisi açısından 21. yüzyıl becerileri-Türkiye'de çocuk üniversiteleri modeli. Yayımlanmamış doktora tezi, İstanbul Üniversitesi Sosyal Bilimler Enstitüsü, İstanbul. 